\title{
Acanthocolpidae (Digenea) of marine fishes off New Caledonia, with the descriptions of two new species
}

\author{
Rodney A. Bray ${ }^{1}$ and Jean-Lou Justine ${ }^{2,3}$ \\ ${ }^{1}$ Department of Zoology, Natural History Museum, Cromwell Road, London SW7 5BD, UK; \\ ${ }^{2}$ UMR 7138 Systématique, Adaptation, Évolution, Muséum National d'Histoire Naturelle, 57, rue Cuvier, 75231 Paris cedex 05 , \\ France; \\ ${ }^{3}$ Aquarium des Lagons, B.P. 8185, 98807 Nouméa, Nouvelle-Calédonie
}

\begin{abstract}
The following acanthocolpid species are reported from New Caledonia. Acaenodera nautili sp. n. from Conger cinereus Rüppel differs from other Acaenodera species in details of the body-spination, the sucker-ratio and the bipartite seminal vesicle; Stephanostomum murielae sp. n. from Carangoides hedlandensis (Whitley) differs from most species of Stephanostomum in the average of 36 circum-oral spines, the circum-oral spine rows with a ventral hiatus and the anterior extent of the vitellarium being $>10 \%$ of the hindbody length from ventral sucker. The species is distinguished from the three other species with these characters in a detailed review. The other species reported are: Stephanostomum aaravi Bray et Cribb, 2003 from Lethrinus miniatus and L. rubrioperculatus; Stephanostomum ditrematis (Yamaguti, 1939) from Gnathanodon speciosus; Stephanostomum japonocasum Durio et Manter, 1969 from Cephalopholis urodeta, Epinephelus areolatus, E. chlorostigma, E. maculatus, E. retouti, Lethrinus miniatus and Variola louti; Stephanostomum uku Yamaguti, 1970 and Pleorchis uku Yamaguti, 1970 from Aprion virescens.
\end{abstract}

Keywords: Digenea, Acanthocolpidae, Acaenodera, Pleorchis, Stephanostomum, New Caledonia

In this paper we are adding to the sparse knowledge of the acanthocolpids of fishes from the coast of New Caledonia. Durio and Manter (1969) reported two Stephanostomum species, $S$. japonocasum Durio et Manter, 1969 and S. casum (Linton, 1910) and Justine et al. (2010) recorded the former again. Bray and Justine (2007) mentioned an immature Stephanostomum in a balistid. We have identified members of three acanthocolpid genera and report on one new species of Acaenodera Manter et Pritchard, 1960, one species of Pleorchis Railliet, 1896 and five species of Stephanostomum Looss, 1899, including one new species.

\section{MATERIALS AND METHODS}

Most fish were caught by hook and line, a few were bought at the fish market or spear-fished and the conger was taken in a baited cage for the collection of Nautilus at a depth of $400 \mathrm{~m}$. Digeneans were collected live, immediately fixed in nearly boiling saline and then transferred to $80 \%$ ethanol (Cribb and Bray 2010). Whole-mounts were stained with Mayer's paracarmine, cleared in beechwood creosote and mounted in Canada balsam. Measurements were made through a drawing tube on an Olympus BH-2 microscope, using a Digicad Plus digitising tablet and Carl Zeiss KS100 software adapted by Imaging Associates, and are quoted in micrometres. The following abbreviations are used: BMNH, British Museum (Natural History) Collection at the
Natural History Museum, London, UK; MNHN JNC, Muséum National d'Histoire Naturelle, Paris, France; IPCAS, Institute of Parasitology, Biology Centre of the Academy of Sciences of the Czech Republic, České Budějovice, Czech Republic.

\section{RESULTS}

Acanthocolpidae Lühe, 1906

Acaenodera Manter et Pritchard, 1960

Acaenodera nautili sp. n.

Figs. 1-4

Description. Based on 7 whole-mounts, 4 measured, measurements and ratios in Table 1. Specimens difficult to mount exactly dorso-ventrally. Body elongate, narrow, cylindrical, narrower forebody (Fig. 1). No eyespots seen. Forebody spination complicated (Figs. 2-3). About 19 rows of three (usually) or four large spines in midventral region. These spines are irregular, fairly blunt, and gradually reduce in size to merge with usual body-spines at about level of pharynx; anteriormost spines 60-76 long, spines in 19th row 32-43 long. Each lateral region with about 19 rows of 5 to 6 spines, similar in structure to those of mid-ventral region; anteriormost spines 50-74 long. Large spines apparently overlain by layer of tegument. Between mid-ventral and lateral large spine fields, and dorsally between lateral large spine fields are rows of 

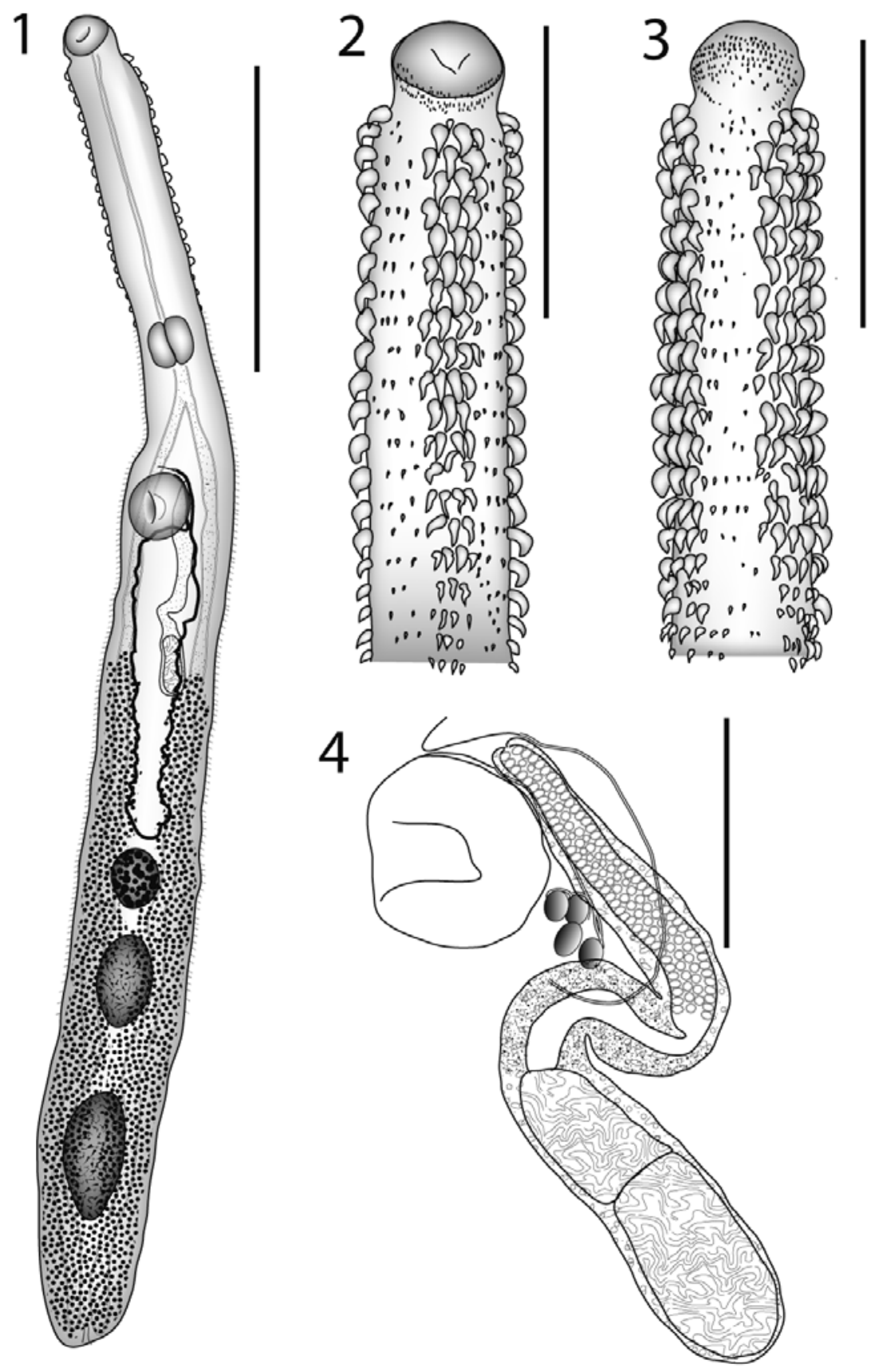

Figs. 1-4. Acaenodera nautili sp. n. from Conger cinereus. Fig. 1. Ventral view of holotype, uterus in outline, detail of forebody spination omitted. Fig. 2. Ventral view of forebody spination. Fig. 3. Dorsal view of forebody spination. Fig. 4. Lateral view of terminal genitalia, lining of metraterm omitted for clarity. Scale bars: Fig. $1=1000 \mu \mathrm{m}$; Figs. $2,3=500 \mu \mathrm{m}$; Fig. $4=200 \mu \mathrm{m}$.

small acicular intercalary spines about 11-20 long, more or less in line with the large spine rows, apparently easily lost, particularly dorsally. Hindbody spination reaches to about anterior testis. Oral sucker oval, terminal. Oral spination formed of irregular rows of small acicular spines, about three ventrally and up to about six dorsally. Ventral sucker rounded, slightly protuberant. Prepharynx long, straight. Pharynx oval. Oesophagus short. Intestinal bifurcation in posterior forebody. Caeca reach to posterior extremity: uroproct not apparent.
Testes two, oval, entire, tandem, separated, in posterior half of hindbody. Cirrus-sac long, claviform, sinuous, reaches to about mid-distance between ventral sucker and ovary (Fig. 4). Seminal vesicle large, bipartite. Pars prostatica short, not highly glandular. Ejaculatory duct lined throughout with pavement of thin-walled irregular cupolas. Genital atrium short. Genital pore median, immediately anterior to ventral sucker.

Ovary oval, entire, pre-testicular, separated from anterior testis. Uterine seminal receptacle in proximal uterus. 
Mehlis' gland antero-dextral to ovary. Laurer's canal opens dorsally to ovary. Uterus mostly intercaecal between ovary and ventral sucker. Eggs numerous, tanned, operculate. Metraterm about half length of cirrus-sac, lined in similar fashion to ejaculatory duct. Vitellarium follicular, reaching from about mid-way between ventral sucker and ovary anteriorly and posterior extremity; in lateral fields, ventral, lateral and dorsal to caeca, overlaps gonads, almost confluent or confluent between testes, confluent in post testicular region.

Excretory pore terminal. Excretory vesicle not traced.

Type-host: Conger cinereus Rüppell, Congridae, longfin African conger.

Site: Digestive tract.

Type-1 oc ality: Deep Sea 400 m, near Passe de Dumbéa, off Nouméa, New Caledonia (03/07/2009).

Prevalence: 1 of 1 .

Specimens: Holotype MNHN JNC2993B-1, paratypes MNHN JNC2993B-2-4; BMNH 2010.9.29.1-3; IPCAS D-689.

E ty molog y: Named after Nautilus. The host was captured in a Nautilus trap.

Discussion. The type-species of this genus, Acaenodera placophora Manter et Pritchard, 1960, is known from the longfin African conger Conger cinereus Rüppell (syn. Conger marginatus Valenciennes) from off Hawaii (Manter and Pritchard 1960, Yamaguti 1970). The only other confirmed report of this genus is that of A. spinosior Etchegoin, Lanfranchi, Cremonte et Timi, 2006 from the Argentine conger Conger orbignianus Valenciennes, off Mar del Plata, Argentina (Etchegoin et al. 2006). Manter and Pritchard (1960) thought that the species Stephanostomum robustum (MacCallum, 1917) from the European conger eel Conger conger (Linnaeus) from New York Aquarium (MacCallum 1917) probably belonged in Acaenodera, but the material was too poor to be certain. The spination of the forebody is unusual in this genus and confusingly described, but well illustrated, for A. placophora. Manter and Pritchard (1960) stated 'Three distinct sets of spines present: (1) small, sharp body spines decreasing in both size and number from a level anterior to pharynx to level of ovary; (2) 2 lateral groups of 12 to 18 conspicuously enlarged, recurved spines extending from just posterior to oral sucker to level of eyespots, decreasing in size to merge with body spines ...; ; (3) 17 flat plates in 7 midventral rows (2-3-2-3-2-3-2) beginning just posterior to oral sucker and decreasing in size to level of eyespots ... . No peribuccal spines. Spines, particularly the large ones, may be lost in macerated specimens; lateral spines may leave basal stumps only'. Yamaguti (1970) said 'Although Manter \& Pritchard (1960) stated in their original description that there are no peribuccal spines, I have clearly observed five alternating, circumoral rows of sharp spines; the spines are more distinct (up to 13-18 $\mu$ long) on the dorsal side than on the ventral side where the anterior spines may be missing or rudimentary. Body spines sharply pointed,
9-12 $\mu$ long, decreasing in size and number posteriorly. Of the five lateral cervical spines the anterior two are larger than the posterior three, up to $60-160 \mu$ long; ventrolateral spines are arranged in five transverse rows of two or three each, beginning just posterior to oral sucker, up to $80-170 \mu$ long; they are followed by several transverse rows of distinctly smaller spines.' We have illustrated and described the situation in our material and as far as we can tell the basic pattern is similar to that described by Manter and Pritchard (1960) and Yamaguti (1970). As the spines in the mid-ventral rows decrease in size gradually until they are indistinguishable from the regular body-spines, it is not easy to accurately assess how many rows there are. We reckon that in our specimens there are about 19. Manter and Pritchard (1960) described and illustrated 7 rows, and Yamaguti (1970) illustrated about 14 rows, the posterior 7 of which are distinctly smaller than the anterior seven. We are confused by Yamaguti's (1970) description and cannot ascertain how many mid-ventral rows he is describing. We reckon that, in our specimens, the spines in the anterior 12 rows are of similar size and the diminution in size occurs between about rows 13 and 19. Etchegoin et al. (2006) described 18-20 rows of enlarged mid-ventral spines and illustrated about 12 rows of large hooks and reduced size posterior to that. This arrangement is similar to that in our specimens. Thus in this feature $A$. nautili differs from $A$. placophora, but not $A$. spinosior. In the illustrations in Yamaguti (1970) and Etchegoin et al. (2006) the hooks appear acicular, rather than blunt and curved as in our specimens.

Acaenodera nautili is similar to the described species but is distinctly narrower, with a relatively longer forebody (see width ratios in Table 1) (it should be noted, however, that our specimens are not flattened). The ventral sucker is relatively smaller (see sucker ratios in Table 1 ) and the testes are distinctly separated. In addition A. nautili differs from $A$. spinosior in the relatively shorter cirrus-sac (see ratios in Table 1). The seminal vesicle in A. nautili appears bipartite, a condition not described in the other species.

\section{Pleorchis Railliet, 1896}

\section{Pleorchis $\boldsymbol{u k u}$ Yamaguti, 1970}

H o st: Aprion virescens Valenciennes, Lutjanidae, green jobfish. Site: Digestive tract.

Locality: Récif Snark off Nouméa, New Caledonia $\left(22^{\circ} 26^{\prime} \mathrm{S}, 166^{\circ} 25^{\prime} \mathrm{E}, 05 / 06 / 2008\right)$.

Prevalence: 1 of 2 .

Vou chers: MNHN JNC2568.

Discussion. All specimens are immature. This species has been reported in Aprion virescens from Hawaii (Yamaguti 1970), off Xisha Islands, China (Gu and Shen 1983) and from Lizard Island on the Great Barrier Reef (Bray et al. 2005). The host is unusual for a member of this genus, in that most species are parasites of sciaenids 
Table 1. Measurements and ratios of Acaenodera spp.

\begin{tabular}{|c|c|c|c|c|}
\hline Species & Acaenodera nautili sp. $\mathrm{n}$. & $\begin{array}{l}\text { Acaenodera } \\
\text { placophora }\end{array}$ & $\begin{array}{l}\text { Acaenodera } \\
\text { placophora }\end{array}$ & Acaenodera spinosior \\
\hline Host & Conger cinereus & Conger cinereus & Conger cinereus & Conger orbignyanus \\
\hline Source & Original & $\begin{array}{l}\text { Manter and Pritch- } \\
\text { ard (1960) }\end{array}$ & Yamaguti (1970) & Etchegoin et al. (2006) \\
\hline Locality & New Caledonia & Hawaii & Hawaii & Argentina \\
\hline $\mathrm{n}$ & 4 & 5 & 31 & 12 \\
\hline Length & $4,546-4,608(4,575)$ & $2,370-3,351$ & $2,300-5,650$ & $5,140-7,140(6,170)$ \\
\hline Width & $393-453(430)$ & $438-533$ & $300-770$ & $560-1,000(714)$ \\
\hline Forebody & $1,615-1,761(1,662)$ & & & $1,160-2,330(1,742)$ \\
\hline Ventral spine row number & $18-19(19)$ & 7 & [about 14] & $18-20$ \\
\hline Ventral spine & $46-63(55)$ & & $\begin{array}{l}\text { 'ventrolateral' } \\
\text { up to } 80-170\end{array}$ & $90-130(110)$, reducing to $46-65$ (58) \\
\hline Intercalary small spines & $15-21(19)$ & & & \\
\hline Oral sucker & $121-132 \times 161-178(128 \times 171)$ & $94-119 \times 60-73$ & $50-130 \times 80-130$ & $120-168 \times 160-184(147 \times 167)$ \\
\hline Prepharynx & $840-987$ (907) & $400-550$ & $180-750$ & $740-1,240(956)$ \\
\hline Pharynx & $154-179 \times 122-152(167 \times 132)$ & $95-146 \times 88-121$ & $80-150 \times 80-130$ & $168-240 \times 136-200(207 \times 160)$ \\
\hline Oesophagus & $138-202(173)$ & & $50-300$ & $60-136(107)$ \\
\hline IB to VS & $246-296(269)$ & & & \\
\hline Ventral sucker & $221-235 \times 210-254(226 \times 223)$ & $190-241 \times 180-238$ & & $360-512 \times 328-500(412 \times 395)$ \\
\hline Cirrus-sac & $784-913 \times 90-111(849 \times 102)$ & & $400-720 \times 70-110$ & $1,660-1,900 \times 85-300(1,838 \times 207)$ \\
\hline Cirrus-overlap into hindbody & $464-510(486)$ & & & \\
\hline VS to vitellarium & $226-357(285)$ & & & $130-650(299)$ \\
\hline VS to ovary & $969-1,001(988)$ & & & $1,330-2,300(1,717)$ \\
\hline Ovary & $212-244 \times 161-183(227 \times 174)$ & $133-161 \times 124-175$ & $100-250 \times 100-250$ & $176-340 \times 248-400(267 \times 305)$ \\
\hline Ovary to anterior testis & $28-88(65)$ & & & \\
\hline Anterior testis & $257-331 \times 162-227(306 \times 195)$ & $289-380 \times 162-241$ & $\begin{array}{l}250-900 \times 170-350 \\
\text { (both testes) }\end{array}$ & $488-900 \times 240-600(711 \times 416)$ \\
\hline Distance between testes & $156-214(181)$ & & & $0-230(73)$ \\
\hline Posterior testis & $455-471 \times 201-268(461 \times 228)$ & $316-496 \times 170-212$ & $\begin{array}{l}250-900 \times 170-350 \\
\text { (both testes) }\end{array}$ & $504-1,300 \times 272-580(891 \times 435)$ \\
\hline Post-testicular distance & $387-419(398)$ & & & $260-780(472)$ \\
\hline Post-caecal distance & $31-91(60)$ & & & $75-460(181)$ \\
\hline Eggs & $77-92 \times 38-44(85 \times 42)$ & $60-74 \times 46-61$ & $67-81 \times 46-58$ & $65-95 \times 48-59(75 \times 53)$ \\
\hline Width $\% *$ & $8.61-9.87(9.40)$ & $\{15.9-18.5\}$ & $\{13.0-13.6\}$ & $\{10.9-14.0\}$ \\
\hline Forebody $\% *$ & $35.4-38.2(36.3)$ & {$[27]$} & {$[25]$} & $\{22.6-32.6\}$ \\
\hline Sucker-length ratio & $1: 1.67-1.87(1: 1.76)$ & $\{1: 2.0\}$ & {$[1: 3]$} & $1: 2.4-3.4(1: 2.7)$ \\
\hline Sucker-width ratio & $1: 1.20-1.50(1: 1.31)$ & $1: 2.0-2.4\{1: 3.0-3.3\}$ & {$[1: 2.1]$} & $1: 2.0-2.8(1: 2.4)$ \\
\hline Cirrus-sac length $\% *$ & $17.2-19.9(18.5)$ & & $\{12.7-17.4\}$ & 29.8 \\
\hline VS-CS $\%$ VS-Ov & $46.3-50.9(49.2)$ & & [33] & {$[42]$} \\
\hline VS to vitellarium $\% *$ & $4.91-7.83(6.24)$ & {$[7.5]$} & {$[0]$} & $\{2.5-9.1\}$ \\
\hline VS-Ov\%* & $21.0-22.0(21.6)$ & [31] & [21] & $\{26-32\}$ \\
\hline $\mathrm{Ov}-\mathrm{AT} \% *$ & $0.62-1.92(1.41)$ & 0 & {$[0.9]$} & {$[2.3]$} \\
\hline Distance between testes\%* & $3.38-4.69(3.96)$ & {$[1.5]$} & $0-?[0]$ & $\{0-3.2\}$ \\
\hline Post-testicular region $\% *$ & $8.41-9.15(8.71)$ & {$[6]$} & {$[8]$} & $\{5.1-10.9\}$ \\
\hline Oral sucker length $\% *$ & $2.66-2.91(2.80)$ & $\{3.6-4.0\}$ & $\{2.2-2.3\}$ & $\{2.3-2.4\}$ \\
\hline Ventral sucker length $\% *$ & $4.85-5.11(4.93)$ & $\{7.2-8.0\}$ & {$[8]$} & $\{7.0-7.2\}$ \\
\hline Prepharynx $\% *$ & $18.3-21.4(19.8)$ & $\{16.4-16.9\}$ & $\{7.8-13.3\}$ & $\{14.4-17.4\}$ \\
\hline Pharynx length $\% *$ & $3.37-3.94(3.64)$ & $\{4.0-4.4\}$ & $\{2.7-3.5\}$ & $\{3.3-3.4\}$ \\
\hline Anterior testis length $\% *$ & $5.61-7.28(6.69)$ & $\{11.3-12.2\}$ & {$[13.6]$} & $\{9.5-12.6\}$ \\
\hline Posterior testis length $\% *$ & $9.92-10.2(10.1)$ & $\{13.3-14.8\}$ & {$[17.4]$} & $\{9.8-18.2\}$ \\
\hline Ovary length $\% *$ & $4.66-5.36(4.96)$ & $\{4.8-5.6\}$ & $\{4.3-4.4\}$ & $\{3.4-4.8\}$ \\
\hline Hindbody (HB) & $2,612-2,734(2,687)$ & & & $3,932-4,900(3,932)$ \\
\hline Hindbody $\% *$ & $56.7-59.7(58.7)$ & {$[67]$} & {$[67]$} & $\{69-76\}$ \\
\hline VS-Vit \% HB & $8.66-13.1(10.6)$ & {$[11]$} & {$[0]$} & $\{3.3-13.3\}$ \\
\hline
\end{tabular}

* percentage of body-length; \{within curly brackets are estimates derived from published ranges\}, [within square brackets are estimates derived from published illustrations]

(Bray 2005). Pleorchis uku has also been reported from the crimson jobfish Pristipomoides filamentosus (Valenciennes) (Lutjanidae) and the redbelly yellowtail fusilier Caesio cuning (Bloch) (Caesionidae) off Xisha Islands, China (Gu and Shen 1983). Molecular phylogenies pre- sented by Miller et al. (2007) indicated that the Caesionidae is embedded within the Lutjanidae, so these findings suggest that $P . u k u$ is a specific parasite of lutjanids. The record of $P$. uku from the camouflage grouper Epinephelus polyphekadion (Bleeker) (Serranidae) from off the 
Maldives Island in the Indian Ocean needs confirmation (Lorber et al. 2006).

\section{Stephanostomum Looss, 1899}

Bray and Cribb (2003) listed the then known species of Stephanostomum Looss, 1899. Since then several species have been erected (the circum-oral spine number (COS) and information on the presence $(\mathrm{VH})$ or absence (VC, i.e. ventral continuum) of a ventral hiatus in the COS rows are indicated in parentheses, LHH signifies two lateral hiatuses): S. qatarense Saoud, Nahhas, Al Kuwari et Ramadan, 2002 (COS 35-35, VC), S. beukelaardori Bray et Reimer, 2004 (COS 33-38, VC), S. euzeti Bartoli et Bray, 2004 (COS 49-51, VC), S. tantabiddii Bray et Cribb, 2004 (COS 38-45, VH), S. fijiensis Nahhas, Nasser et Tam, 2004 (COS 44-48, VC), S. talakitok Bray et Cribb, 2006 (COS 34-40, VC), S. adlardi Bray, Cribb, Waeschenbach et Littlewood, 2007 (COS 30-31, LHH), S. gibsoni Shaukat et Bilqees, 2007 (COS 38-41, VC), S. lamothei Bray et Cribb, 2008 (COS 50-55, VC) and S. tupatupa Bray et Cribb, 2008 (COS 34-36, VC) (Saoud et al. 2002, Bartoli and Bray 2004, Bray and Cribb 2004, 2006, 2008, Bray and Reimer 2004, Nahhas et al. 2004, Bray et al. 2007, Shaukat and Bilqees 2007).

\section{Stephanostomum murielae sp. $\mathrm{n}$.}

Figs. 5-7

Description. Based on 9 whole-mount preparations, 6 measured. Measurements and ratios in Table 2. Body elongate, narrow, widest in region of gonads (Fig. 5). Tegument spinous, unarmed patch immediately posterior to oral sucker, spines large, acuminate in forebody, smaller in hindbody, becoming sparse in hindbody, detectable to varying levels in hindbody, in some cases to posterior testis. Oral sucker terminal, distinctly wider than long. Circum-oral spines in double ring, with distinct ventral hiatus (Fig. 6). Ventral sucker rounded, in anterior fifth of body. Prepharynx long. Pharynx pyriform. Oesophagus short. Intestinal bifurcation in posterior forebody. Caeca long, narrow, terminations often obscured by vitellarium, but uroproct sometimes detected.

Testes 2, rounded to oval, entire, tandem, separated by vitelline follicles. Post-testicular region short. Cirrus-sac elongate (Figs. 5, 7), reaches well into hindbody; anterior extremity dorsal to about mid-ventral sucker. Seminal vesicle claviform, undivided, narrows anteriorly. Pars prostatica relatively short, lined with anuclear cell-like bodies, surrounded by gland-cells. Ejaculatory duct long, wide, lined with closely packed small cupolas, with round bases seen as circles on wall of duct, with distinct, but short, naked region distally. Genital atrium reaching to mid-ventral sucker. Genital pore median, slit-like, immediately anterior to ventral sucker.

Ovary oval, entire, widely separated from anterior testis. Mehlis' gland antero-dorsal to ovary. Laurer's canal opens dorsally to ovary. Uterine seminal receptacle not seen. Uterus narrow, intercaecal, pre-ovarian. Eggs large, tanned, operculate, in one specimen only. Metraterm slightly shorter than cirrus-sac, lining lacking cupolas or with weakly developed cupolas. Vitellarium follicular, just overlaps posterior end of cirrus-sac; fields confluent ventrally and dorsally to uterus, gaps lateral to gonads, confluent dorsally and ventrally between gonads and in post-testicular region.

Excretory pore terminal. Vesicle I-shaped, anterior extent not detected.

Ty p - h o st: Carangoides hedlandensis (Whitley), Carangidae, bumpnose trevally.

Site: Digestive tract.

Type-1ocality: Nouméa Fish Market, New Caledonia (13/03/2009).

Prevalence: 1 of 1 .

Specimens: Holotype: MNHN JNC2883-1, paratypes JNC2883-2-5, JNC2883C, BMNH 2010.9.29.8-9.

Etymology: This species is named after the mother of the senior author, who died during the preparation of this paper.

Discussion. According to Bray and Cribb (2003) there are three species of Stephanostomum with $10 \%$ or more of the hindbody devoid of vitelline follicles, the circum-oral spine count around 30 and with a ventral hiatus, namely S. megacephalum Manter, 1940, S. bicoronatum (Stossich, 1883), and S. madhaviae Bray et Cribb, 2003. None of the species described since Bray and Cribb (2003) show these features.

Stephanostomum megacephalum was described from the crevalle jack Caranx hippos (Linnaeus) (Carangidae), off Bahia Honda, on the Pacific coast of Panama, off San Francisco on the coast of Ecuador and off White Friars on the Pacific coast of Mexico (Manter 1940), as having 30-32 circum-oral spines, almost always 32 (based on 11 specimens). Manter (1940) also reported a macerated specimen of this species from the horse-eye jack Caranx latus Agassiz (Carangidae) with 30 oral spines. The species has been reported several times since mainly from the Gulf of Mexico or Caribbean Sea in a variety of carangids (Manter 1947, Sparks 1958, Nahhas and Cable 1964, Nahhas and Short 1965, Overstreet 1969, Nahhas and Powell 1971, Fischthal 1977). It has also been reported from carangids in the Red Sea (Parukhin 1970) and off Cochin and Krusadai, India (Zhukov 1977) and in C. hippos and the dwarf mullet Mugil curvidens (Valenciennes) (Mugilidae) off Ghana in the eastern Atlantic Ocean (Fischthal and Thomas 1968). Manter's original description of $S$. megacephalum indicates that it differs from $S$. murielae in being much smaller $(1,431-2,212$ $\times 375-465$ vs. 5,107-6,645 × 184-283), much broader (width $21-26 \%$ of body-length vs. 3-4\%) and with a relatively longer forebody (25-33\% of body-length vs. 17$21 \%$ ). The cirrus-sac is not illustrated in detail, but the cirrus (?ejaculatory duct) is 'spined, extending only slightly posterior to' the ventral sucker, whereas in $S$. murielae the 

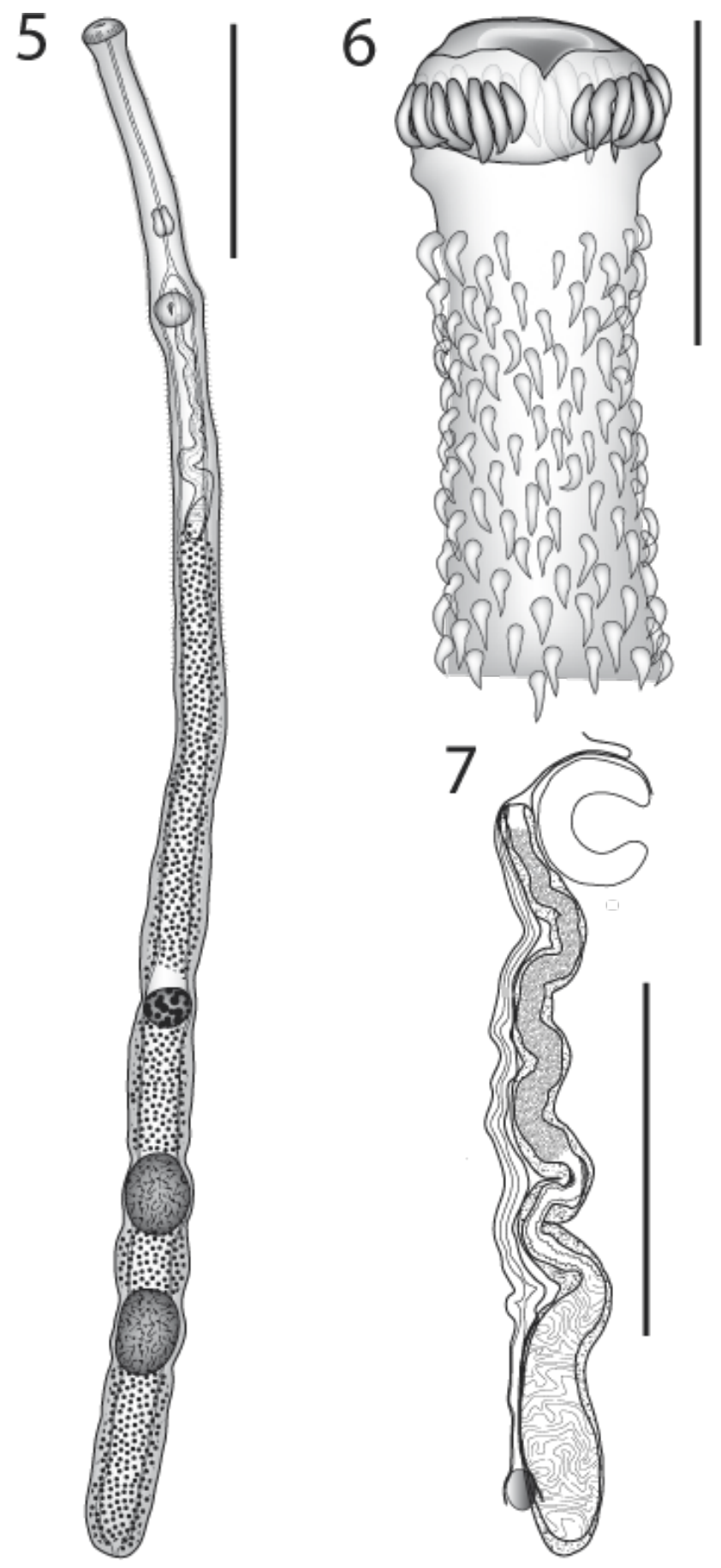

Figs. 5-7. Stephanostomum murielae sp. n. from Carangoides hedlandensis. Fig. 5. Ventral view of holotype, uterus in outline. Fig. 6. Ventral view of oral-sucker and forebody spination. Fig. 7. Lateral view of terminal genitalia. Scale bars: Fig. $5=1000 \mu \mathrm{m}$; Fig. $6=200 \mu \mathrm{m}$; Fig. $7=500 \mu \mathrm{m}$.

ejaculatory duct is long and reaches well into the hindbody. The gonads in $S$. megacephalum are close together or contiguous, with no intervening vitelline follicles and continuous lateral bands of follicles at the level of the go- nads; in S. murielae the gonads are well separated, with intervening vitelline follicles and with the vitelline fields interrupted at the level of the gonads.

Stephanostomum bicoronatum is a reasonably wellstudied widespread parasite, mainly infecting members of the Sciaenidae. The type-host is the shi drum Umbrina cirrosa (Linnaeus) (Sciaenidae), from off Trieste (Stossich 1883). Our comparison of this species is based mainly on its redescription from the brown meagre $\mathrm{Sci}$ aena umbra Linnaeus (Sciaenidae) off Corsica, France by Bartoli and Bray (2001), where they list many of the previous records. Later records are by Lozano et al. (2001) who reported S. bicoronatum from off the southern Iberian coast in the meagre Argyrosomus regius (Asso) (Sciaenidae) giving some dimensions, and by Bray and Cribb (2003) who described the worm from off the southern Queensland coast, Australia in the Madagascar meagre Argyrosomus hololepidotus (Lacepède) (Sciaenidae). Over $80 \%$ of all records are from sciaenids. Bartoli and Bray's (2001) study indicates that $S$. bicoronatum differs from $S$. murielae in being relatively wider (width about $9 \%$ of body length vs. 3-4\%) with a longer forebody (20-30\% of body-length vs. 17-21\%). The genital atrium is longer, reaching to about the posterior margin of the ventral sucker (vs. about mid-ventral sucker). The cirrus-sac reaches $55-57 \%$ of the ventral sucker to ovary distance (vs. 32-38\%). The gonads are only slightly separated or contiguous (vs. distinctly separated). The post-testicular region is shorter (4-5\% of body length vs. $10-11 \%$ ). Judging by the description in Bray and Cribb (2003) S. bicoronatum is relatively wider (width $6-10 \%$ of body-length), with a similar forebody length (15-19\% of body-length), a longer genital atrium, a longer reach of the cirrus-sac into the hindbody (43-54\% of ventral sucker to ovary distance), contiguous testes and with the ovary contiguous or very close to the anterior testis, and a short post-testicular region (3-4\% of body-length). The vitelline fields are not interrupted laterally at the level of the gonads in $S$. bicoronatum.

Stephanostomum madhaviae was described from three specimens from the giant trevally Caranx ignobilis (Forsskål) (Carangidae) by Bray and Cribb (2003) from off Hope Island, southern Queensland, Australia. They considered this to be the same form as described as 'Stephanostomum orientalis (Srivastava, 1939)' by Madhavi (1976) from the Malabar trevally Carangoides malabaricus (Bloch et Schneider) (Carangidae) and the longnose trevally Carangoides chrysophrys (Cuvier) (Carangidae) off the Waltair coast, Bay of Bengal. It differs from $S$. murielae, judging by Bray and Cribb (2003), in being shorter (2,606-3,936 long vs. 5,107-5,645), wider (width 8-9\% of body length vs. 3-4\%), with a longer forebody (28$30 \%$ of body-length vs. $17-21 \%$ ), contiguous gonads (the testes may occasionally be very slightly separated), and a shorter post-testicular region (5-6\% of body length vs. 
Table 2. Measurements and ratios of Stephanostomum spp.

\begin{tabular}{|c|c|c|c|}
\hline $\begin{array}{l}\text { Species } \\
\text { Host } \\
n\end{array}$ & $\begin{array}{l}\text { Stephanostomum murielae sp. } \mathrm{n} . \\
\text { Carangoides hedlandensis } \\
6\end{array}$ & $\begin{array}{l}\text { Stephanostomum aaravi } \\
\text { Lethrinus miniatus } \\
1\end{array}$ & $\begin{array}{l}\text { Stephanostomum ditrematis } \\
\text { Gnathanodon speciosus } \\
1\end{array}$ \\
\hline Length & $5,107-5,645(5,977)$ & 3,901 & 7,660 \\
\hline Width & $184-283(215)$ & 636 & 325 \\
\hline Forebody & $884-1,1270(1,133)$ & 1,141 & 1,222 \\
\hline Oral spine count & $28-31(30)$ & 36 & 36 \\
\hline Anterior ventral spine & $23-40(30)$ & 61 & 41 \\
\hline Posterior ventral spine & $30-50(39)$ & 64 & 36 \\
\hline Anterior dorsal spine & $38-61(50)$ & 55 & 63 \\
\hline Posterior dorsal spine & $46-65(57)$ & 53 & 53 \\
\hline Oral sucker & $70-86 \times 122-147(77 \times 131)$ & $194 \times 201$ & $105 \times 164$ \\
\hline Prepharynx & $512-785(712)$ & 429 & 735 \\
\hline Pharynx & $105-123 \times 73-83(115)$ & $267 \times 227$ & $255 \times 212$ \\
\hline Oesophagus & $33-147(114)$ & 128 & 87 \\
\hline IB to VS & $63-250(116)$ & 121 & 0 \\
\hline Ventral sucker & $118-146 \times 122-138(136 \times 133)$ & $374 \times 377$ & $253 \times 249$ \\
\hline Cirrus-sac & $967-1,205 \times 78-105(1,029 \times 90)$ & $876 \times 102$ & $1,058 \times 88$ \\
\hline Cirrus-overlap into hindbody & $812-1,067(923)$ & 410 & 1,981 \\
\hline VS to vitellarium & 756-934 (845) & 0 & 2,040 \\
\hline VS to ovary & $2,293-2,919(2,599)$ & 752 & 4,160 \\
\hline Ovary & $131-165 \times 103-157(152 \times 133)$ & $216 \times 232$ & $173 \times 136$ \\
\hline Ovary to anterior testis & $336-461(386)$ & 13 & 378 \\
\hline Anterior testis & $284-403 \times 150-200(348 \times 169)$ & $362 \times 219$ & $401 \times 209$ \\
\hline Distance between testes & $72-221(167)$ & 33 & 248 \\
\hline Posterior testis & $308-424 \times 154-227(361 \times 178)$ & $400 \times 248$ & $459 \times 238$ \\
\hline Post-testicular region & $506-708(631)$ & 578 & 312 \\
\hline Eggs & $72 \times 36$ & $88 \times 31$ & $63 \times 28$ \\
\hline Width\%* & $3.19-4.45(3.59)$ & 16.3 & 4.24 \\
\hline Forebody $\% *$ & $17.3-20.6(18.9)$ & 29.3 & 16.0 \\
\hline Sucker-length ratio & $1: 1.69-1.98(1: 1.77)$ & $1: 1.93$ & $1: 2.42$ \\
\hline Sucker-width ratio & 1:0.94-1.12 (1:1.02) & $1: 1.88$ & $1: 1.52$ \\
\hline Cirrus-sac length $\% *$ & $15.9-18.9(17.3)$ & 22.4 & 13.8 \\
\hline VS-CS\%VS-Ov & $31.8-37.9(35.5)$ & 54.6 & 47.6 \\
\hline VS to vitellarium\%* & $12.4-14.9(14.2)$ & 0 & 26.6 \\
\hline VS-Ov\%* & $42.0-44.9(43.5)$ & 19.3 & 54.3 \\
\hline Ov-AT\%* & $5.29-7.58(6.47)$ & 0.32 & 4.94 \\
\hline Distance between testes $\% *$ & $1.27-3.71(2.79)$ & 0.83 & 3.24 \\
\hline Post-testicular region\%* & $9.91-11.2(10.5)$ & 14.8 & 4.08 \\
\hline Oral sucker length\%* & $1.08-1.54(1.30)$ & 4.97 & 1.36 \\
\hline Ventral sucker length\%* & $2.08-2.61(2.28)$ & 9.58 & 3.30 \\
\hline Prepharynx\%* & $10.0-13.5(11.9)$ & 11.0 & 9.59 \\
\hline Pharynx length\%* & $1.84-2.25(1.93)$ & 6.68 & 3.33 \\
\hline Anterior testis length\%* & $5.16-6.92(5.83)$ & 9.29 & 5.23 \\
\hline Posterior testis length\%* & $5.53-6.68(6.04)$ & 10.3 & 5.99 \\
\hline Ovary length\%* & $2.44-2.69(2.55)$ & 5.53 & 2.25 \\
\hline Hindbody (HB) & $4,090-5,233(4,708)$ & 2,386 & 6,185 \\
\hline Hindbody\%* & $77.3-80.1(78.8)$ & 61.2 & 80.7 \\
\hline VS-Vit $\% H B$ & $15.6-18.7(18.0)$ & 0 & 33.0 \\
\hline Genital atrium & $90-125(103)$ & 114 & 1,212 \\
\hline Ejaculatory duct & $367-583(474)$ & 181 & 317 \\
\hline Pars prostatica & $172-248(212)$ & 320 & 366 \\
\hline Seminal vesicle length & $218-478(371)$ & 431 & 347 \\
\hline Male duct & $981-1,188(1,056)$ & 931 & 1029 \\
\hline Ejaculatory duct $\%$ male duct & $36.8-59.5(45.1)$ & 19.4 & 30.8 \\
\hline Pars prostatica $\%$ male duct & $16.5-24.8(20.1)$ & 34.3 & 35.6 \\
\hline SV length\%male duct & $22.2-40.2(34.8)$ & 46.3 & 33.7 \\
\hline
\end{tabular}


$10-11 \%)$. Usually the ejaculatory duct is relatively shorter (36\% of male-duct vs. 37-59 (45)). The vitelline fields are not interrupted laterally at the level of the gonads in S. madhaviae.

\section{Stephanostomum aaravi Bray et Cribb, 2003}

Ho sts : Lethrinus miniatus Forster, Lethrinidae, trumpet emperor; Lethrinus rubrioperculatus Sato, Lethrinidae, spotcheek emperor.

S it es: Digestive tract, stomach.

L o c a liti e s: L. miniatus, Récif Toombo $\left(22^{\circ} 33^{\prime} \mathrm{S}, 166^{\circ} 27^{\prime} \mathrm{E}\right.$, 20/11/2007), L. rubrioperculatus, Récif Toombo (22 $26^{\prime}$ 'S, $\left.166^{\circ} 33^{\prime} \mathrm{E}, 27 / 06 / 2006\right)$, Shallow, Interior Lagoon near Récif Toombo $\left(22^{\circ} 33^{\prime} \mathrm{S}, 166^{\circ} 29^{\prime} \mathrm{E}, 25 / 11 / 2008\right)$, all off Nouméa, New Caledonia.

Prevale n c e: L. miniatus $3.7 \%$ ( 1 of 27 ); L. rubrioperculatus, $12 \%$ (2 of 17).

Vou chers : L. miniatus MNHN JNC2402; L. rubrioperculatus, MNHN JNC1885, JNC2773.

Discussion. These specimens fit comfortably into the original and only description of this species from Lethrinus miniatus off Heron Island, Queensland (Bray and Cribb 2003), although those from L. rubrioperculatus are distorted and not measured (see Table 2 for measurements of specimen from L. miniatus).

\section{Stephanostomum ditrematis (Yamaguti, 1939) Manter, 1947}

H o s t: Gnathanodon speciosus (Forsskål), Carangidae, golden trevally.

Site : Digestive tract.

L o c a lity: Nouméa Fish Market (05/12/2008).

Prevalence: $25 \%$ (1 of 4$)$.

Vou chers: MNHN JNC2819C, BMNH 2010.9.29.4.

Discussion. These worms (see Table 2) are indistinguishable from those described as this species from the same species of host off Heron and Lizard Islands on the Great Barrier Reef by Bray and Cribb (2008). The type host was reported as Ditrema temmincki Bleeker (Embiotocidae) from the Inland Sea of Japan (Yamaguti 1939), but most subsequent reports have been from carangids.

\section{Stephanostomum japonocasum Durio et Manter,} 1969

Figs. 8-13

H o s t s: Cephalopholis urodeta (Forster), Serranidae, darkfin hind; Epinephelus areolatus (Forsskål), Serranidae, areolate grouper; Epinephelus chlorostigma (Valenciennes), Serranidae, brownspotted grouper; Epinephelus maculatus (Bloch), Serranidae, highfin grouper; Epinephelus retouti Bleeker, Serranidae, red-tipped grouper; Lethrinus miniatus (Forster), Lethrinidae, trumpet emperor; Variola louti (Forsskål), Serranidae, yellow-edged lyretail.

$\mathrm{S}$ i t e : Intestine, digestive tract.
Localities: C. urodeta, Shallow, Interior Lagoon near Récif Toombo $\left(22^{\circ} 33^{\prime} \mathrm{S}, 166^{\circ} 29^{\prime} \mathrm{E}, 04 / 11 / 2008\right)$; E. areolatus, Off Ilôt Brun et Baie des Citrons $\left(22^{\circ} 17^{\prime} \mathrm{S}, 166^{\circ} 25^{\prime} \mathrm{E}\right.$, 29/04/2008); E. chlorostigma, Off Récif Toombo, deepsea $\left(22^{\circ} 34^{\prime} \mathrm{S}, 166^{\circ} 28^{\prime} \mathrm{E}, 04 / 01 / 2008\right)$; E. maculatus, Récif Toombo $\left(22^{\circ} 26^{\prime} \mathrm{S}, 166^{\circ} 33^{\prime} \mathrm{E}, 14 / 12 / 2005\right)$, Interior Lagoon near Récif Toombo $\left(22^{\circ} 33^{\prime} \mathrm{S}, 1^{166^{\circ}} 29^{\prime} \mathrm{E}, 30 / 04 / 2009\right)$, Near Récif Toombo (2234'S, $\left.166^{\circ} 29^{\prime} \mathrm{E}, 16 / 09 / 2009\right)$; E. retouti,

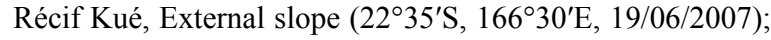
L. miniatus, Récif Kué, External slope $\left(22^{\circ} 35^{\prime} \mathrm{S}, 166^{\circ} 30^{\prime} \mathrm{E}\right.$, 21/06/2007, 22/06/2007), External slope of Récif Toombo (2234'S, $\left.166^{\circ} 27^{\prime} \mathrm{E}, 09 / 10 / 2007\right)$, Off Récif Kué, Middle of Reef $\left(22^{\circ} 36^{\prime} \mathrm{S}, 166^{\circ} 32^{\prime} \mathrm{E}, 09 / 12 / 2008\right)$; V. louti, Récif Kué, External slope $\left(22^{\circ} 35^{\prime} \mathrm{S}, 166^{\circ} 30^{\prime} \mathrm{E}, 21 / 06 / 2007\right)$, all off Nouméa, New Caledonia.

Prevalence: C. urodeta, $25 \%$ (1 of 4$) ; E$. areolatus, $20 \%$ (1 of 5); E. chlorostigma, 33\% (1 of 3); E. maculatus, $12 \%$ (3 of 26); E. retouti, 33\% (1 of 3); L. miniatus, 19\% (5 of 27); V. louti, 8\% (1 of 12$)$.

Vouchers: C. urodeta, MNHN JNC2748; E. areolatus, MNHN JNC2494, JNC3053; E. chlorostigma, MNHN JNC2446; E. maculatus, MNHN JNC1684, JNC2930, BMNH 2010.9.29.5; E. retouti, MNHN JNC2181B; L. miniatus, MNHN JNC2205, JNC2207, JNC2300, JNC2822B, BMNH 2010.9.29.6-7; V. louti, JNC2198.

Discussion. This species is known only from the original record by Durio and Manter (1969) from Epinephelus sp. and an 'unidentified serranid' off New Caledonia and reports from six serranid species off New Caledonia by Justine et al. (2010). We here record the species in six serranid species and one lethrinid (Table 3). The latter is a surprising host as in the lethrinids of the Great Barrier Reef the similar species, S. pagrosomi (Yamaguti, 1939), is reported from Lethrinus miniatus, the spangled emperor L. nebulosus (Forsskål) and the Pacific yellowtail emperor L. atkinsoni Seale, off Heron Island (Bray and Cribb 2003). Stephanostomum pagrosomi, in lethrinids, is reported as having 49-59 uninterrupted circum-oral spines and vitelline fields that reach to about the posterior margin of the ventral sucker. According to our data $S$. japonocasum has 44-53 circum-oral spines and vitelline fields that reach to about the anterior margin of the ventral sucker or just into the forebody and the fields are confluent in the anterior region. The vitelline configuration is a convincing distinction between $S$. japonocasum and S. pagrosomi. Durio and Manter (1969) reported 40-44 circum-oral spines in $S$. japonocasum, distinguishing this species from $S$. japonicum (Yamaguti, 1934) by circum-oral spine number, i.e. $40-44$ vs. 46 . Our data cast doubt on this distinction. No spines were described in the ejaculatory duct or metraterm of $S$. japonicum. We observed cupolas with circular bases on the ejaculatory duct and metraterm walls, which we take to be the same as the spines with 'spherical base' as described by Durio and Manter (1969). The cirrus of S. japonicum is described by Yamaguti (1934) as joining 'the metraterm near the conspicuous genital pore lying immediately' anterior to 
8

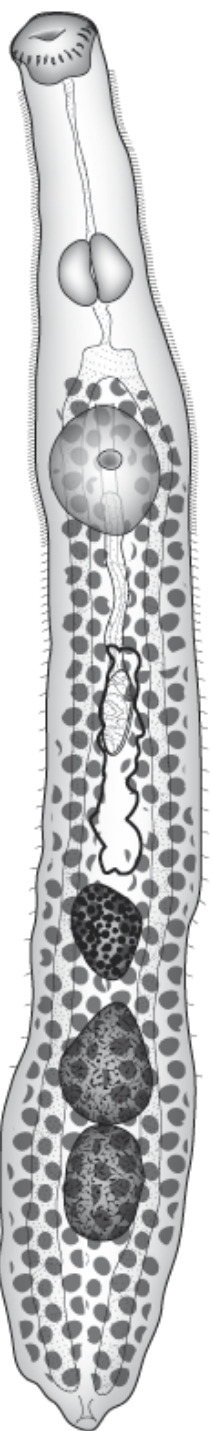

9

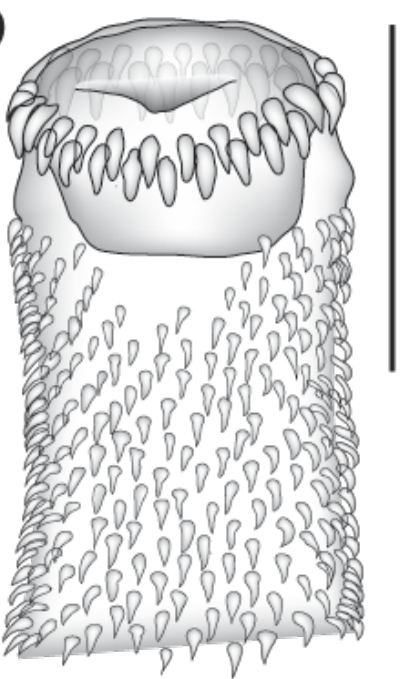

10

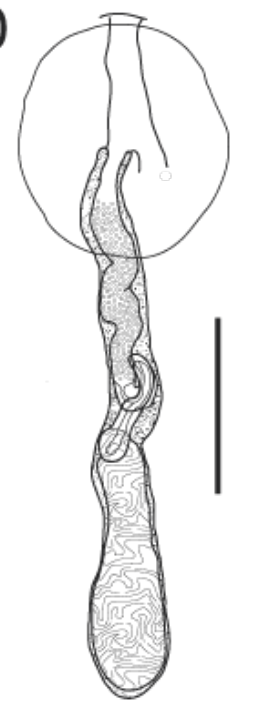

11

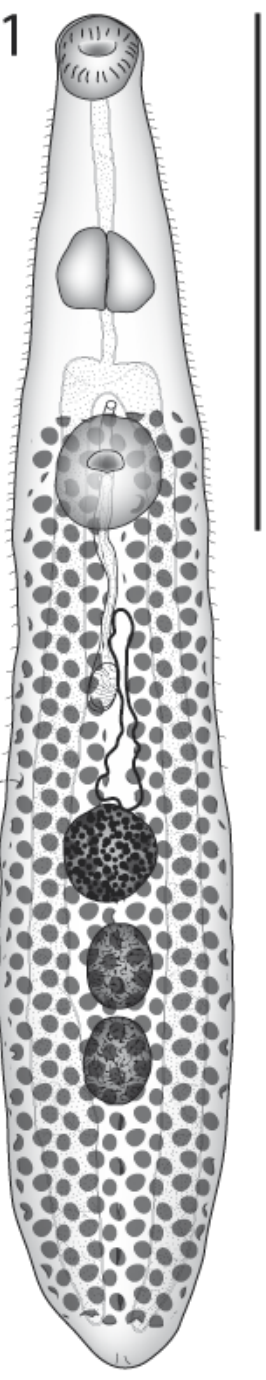

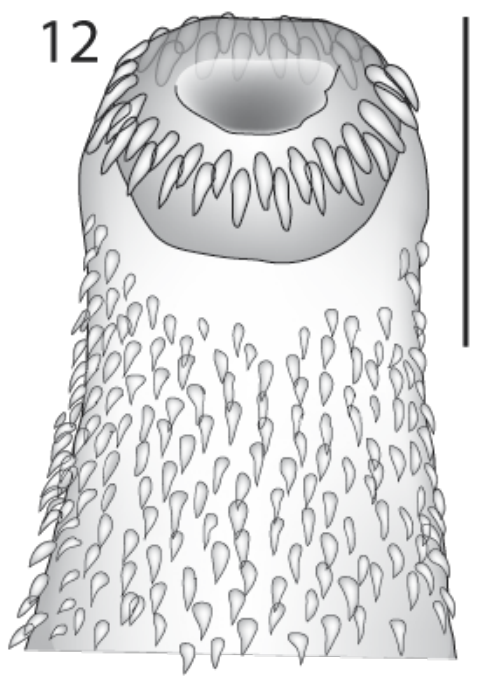

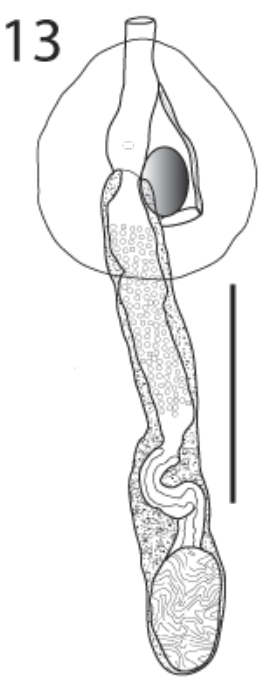

Figs. 8-13. Stephanostomum japonocasum Durio et Manter, 1969 ex Lethrinus miniatus (Figs. 8-10) and ex Epinephelus areolatus (Figs. 11-13). Figs. 8, 11. Ventral view, uterus in outline. Figs. 9, 12. Ventral view of oral-sucker and forebody spination. Figs. 10, 13. Lateral view of terminal genitalia. Scale bars: Fig. $8=500 \mu \mathrm{m}$; Figs. $9,10,12,13=200 \mu \mathrm{m}$. Fig. $11=1000 \mu \mathrm{m}$.

the ventral sucker. In S. japonocasum the ejaculatory duct (= cirrus) joins the metraterm at about mid-ventral sucker level, and there is a distinct elongate genital atrium. These features associated with the terminal genitalia may serve to distinguish $S$. japonicum from S. japonocasum. There is also no evidence that the vitelline fields in S. japonicum are confluent in the anterior region or in the posterior forebody, as in S. japonocasum. Stephanostomum japonicum has been reported only in the spinyhead sculpin Dasycottus setiger Bean and Cottunculus sp. (Psychrolutidae) and the hookhorn sculpin Artediellus pacificus Gilbert (Cottidae) from Toyama Bay, Japan (Yamaguti 1934). We disagree with Machida (1984) who considered $S$. japonicum a synonym of $S$. baccatum (Nicoll, 1907), a widespread northern temperate species, originally described from the Atlantic halibut Hippoglossus hippoglossus (Linnaeus)
(Pleuronectidae) off Scotland (Nicoll 1907). In S. baccatum the vitellarium does not reach into the forebody (Nicoll 1907, 1913, Manter 1926, Wolfgang 1955, Zhukov 1960, Machida 1984).

All specimens of Lethrinus miniatus and several of the serranids were taken outside the barrier reef in relatively deep water and, therefore, they share a common environment and probably common prey items which act as second intermediate hosts of S. japonocasum. Lethrinus miniatus is a relatively large predator as are most of the serranids (apart from Cephalopholis urodeta). The prevalence of $S$. japonocasum in L. miniatus was $19 \%$, and in serranids the prevalence varied between $8 \%$ and $33 \%$, suggesting that $L$. miniatus is not an accidental host. Other lethrinid species from within the lagoon apparently do not harbour this digenean, but they are smaller species. 
Table 3. Measurements and ratios of Stephanostomum japonocasum.

\begin{tabular}{|c|c|c|c|c|}
\hline Species & $\begin{array}{l}\text { Stephanostomum } \\
\text { japonocasum }\end{array}$ & $\begin{array}{l}\text { Stephanostomum } \\
\text { japonocasum }\end{array}$ & $\begin{array}{l}\text { Stephanostomum } \\
\text { japonocasum }\end{array}$ & $\begin{array}{l}\text { Stephanostomum } \\
\text { japonocasum }\end{array}$ \\
\hline Host & Cephalopholis urodeta & Epinephelus areolatus & Epinephelus chlorostigma & Epinephelus maculatus \\
\hline $\mathrm{n}$ & 1 & 1 & 1 & \\
\hline Length & 2,247 & 2,741 & 3,786 & $2193-2,289$ \\
\hline Width & 293 & 466 & 492 & $367-396$ \\
\hline Forebody & 814 & 788 & 942 & $655-802$ \\
\hline Oral spine count & 48 & 44 & 45 & $46-51$ \\
\hline Anterior ventral spine & 32 & 31 & 36 & $36-40$ \\
\hline Posterior ventral spine & 39 & 35 & 43 & $36-37$ \\
\hline Anterior dorsal spine & 35 & 18 & 43 & $22-27$ \\
\hline Posterior dorsal spine & 49 & 25 & 59 & $36-37$ \\
\hline Oral sucker & $137 \times 171$ & $145 \times 171$ & $161 \times 214$ & $140-151 \times 157-168$ \\
\hline Prepharynx & 359 & 262 & 320 & $220-290$ \\
\hline Pharynx & $150-138$ & $177 \times 198$ & $185 \times 195$ & $164-170 \times 161-175$ \\
\hline Oesophagus & 74 & 91 & 131 & $61-105$ \\
\hline IB to VS & 93 & 103 & 145 & $75-89$ \\
\hline Ventral sucker & $234 \times 188$ & $228 \times 214$ & $306 \times 273$ & $215-229 \times 167-229$ \\
\hline Cirrus-sac & $504 \times 54$ & $494 \times 97$ & $670 \times 79$ & $467-492 \times 57-88$ \\
\hline Cirrus-overlap into hindbody & 206 & 364 & 529 & $315-356$ \\
\hline VS to vitellarium & 0 & 0 & 0 & $0-51$ \\
\hline VS to ovary & 384 & 566 & 920 & $410-471$ \\
\hline Ovary & $140 \times 108$ & $192 \times 179$ & $239 \times 208$ & $92-147 \times 92-118$ \\
\hline Ovary to anterior testis & 64 & 35 & 136 & $14-26$ \\
\hline Anterior testis & $171 \times 122$ & $179 \times 132$ & $291 \times 192$ & $150-152 \times 112-154$ \\
\hline Distance between testes & 0 & 0.51 & 0 & 0 \\
\hline Posterior testis & $173 \times 119$ & $176 \times 119$ & $310 \times 179$ & $138-144 \times 107-144$ \\
\hline Post-testicular region & 264 & 523 & 616 & $390-444$ \\
\hline Eggs & $75 \times 32$ & $64 \times 44$ & $81 \times 36$ & $52-75 \times 32-38$ \\
\hline Width\%* & 13.1 & 17.0 & 13.0 & $16.8-17.3$ \\
\hline Forebody $\% *$ & 36.2 & 28.8 & 24.9 & $29.9-35.0$ \\
\hline Sucker-length ratio & $1: 1.70$ & $1: 1.57$ & $1: 1.90$ & $1: 1.52-1.53$ \\
\hline Sucker-width ratio & $1: 1.10$ & $1: 1.25$ & $1: 1.28$ & $1: 1.06-1.36$ \\
\hline Cirrus-sac length\%* & 22.4 & 18.0 & 17.7 & $21.3-21.5$ \\
\hline VS-CS\%VS-Ov & 53.8 & 64.3 & 57.5 & $75.6-76.8$ \\
\hline VS to vitellarium $\% *$ & 0 & 0 & 0 & $0-2.2$ \\
\hline VS-Ov\%* & 17.1 & 20.7 & 24.3 & $18.7-20.6$ \\
\hline Ov-AT\%* & 2.83 & 1.29 & 3.60 & $0.64-1.1$ \\
\hline Distance between testes $\% *$ & 0.00 & 0.51 & 0.00 & 0.00 \\
\hline Post-testicular region\%** & 11.7 & 19.1 & 16.3 & $17.0-20.3$ \\
\hline Oral sucker length\%** & 6.12 & 5.29 & 4.25 & $6.4-6.6$ \\
\hline Ventral sucker length\%** & 10.4 & 8.31 & 8.09 & $9.79-10.0$ \\
\hline Prepharynx\%* & 16.0 & 9.56 & 8.47 & $10.0-12.7$ \\
\hline Pharynx length\%** & 6.69 & 6.47 & 4.88 & $7.41-7.48$ \\
\hline Anterior testis length\%* & 7.61 & 6.54 & 7.68 & $6.62-6.84$ \\
\hline Posterior testis length\%* & 7.69 & 6.43 & 8.19 & $6.01-6.56$ \\
\hline Ovary length\%* & 6.23 & 6.99 & 6.30 & $4.03-6.72$ \\
\hline Hindbody (HB) & 1,200 & 1,725 & 2,537 & $1,259-1,324$ \\
\hline Hindbody $\% *$ & 53.4 & 62.9 & 67.0 & $55.0-60.3$ \\
\hline VS-Vit $\% H B$ & 0 & 0 & 0 & $0-4.1$ \\
\hline Genital atrium & 72 & 141 & 199 & $126-136$ \\
\hline Ejaculatory duct & 273 & 266 & 376 & 219-316 \\
\hline Pars prostatica & 132 & 227 & 99 & 139-172 \\
\hline Seminal vesicle length & 143 & 110 & 199 & $72-127$ \\
\hline Male duct & 548 & 603 & 674 & $485-560$ \\
\hline Ejaculatory duct $\%$ male duct & 49.9 & 44.1 & 55.7 & $45.3-56.5$ \\
\hline Pars prostatica $\%$ male duct & 24.1 & 37.6 & 14.7 & $28.6-30.7$ \\
\hline SV length\%male duct & 26.0 & 18.3 & 29.6 & $12.8-26.2$ \\
\hline
\end{tabular}


Table 3. Continued.

\begin{tabular}{|c|c|c|c|}
\hline $\begin{array}{l}\text { Species } \\
\text { Host } \\
\mathrm{n}\end{array}$ & $\begin{array}{l}\text { Stephanostomum japonocasum } \\
\text { Epinephelus retouti } \\
1 \text {, poor specimen }\end{array}$ & $\begin{array}{l}\text { Stephanostomum japonocasum } \\
\text { Lethrinus miniatus } \\
3\end{array}$ & $\begin{array}{l}\text { Stephanostomum japonocasum } \\
\text { Variola louti } \\
1\end{array}$ \\
\hline Length & 2,933 & $2,618-3,362(3,007)$ & 2558 \\
\hline Width & 513 & $370-469(422)$ & 383 \\
\hline Forebody & 776 & $730-941(838)$ & 783 \\
\hline Oral spine count & 46 & $45-53(48)$ & 50 \\
\hline Anterior ventral spine & 30 & $26-34(30)$ & 32 \\
\hline Posterior ventral spine & 33 & $28-34(31)$ & 33 \\
\hline Anterior dorsal spine & 41 & $24-33(28)$ & 32 \\
\hline Posterior dorsal spine & 49 & $34-43(39)$ & 35 \\
\hline Oral sucker & $147 \times ?$ & $107-160 \times 148-198(129 \times 174)$ & $129 \times 187$ \\
\hline Prepharynx & 281 & $261-369(321)$ & 338.2 \\
\hline Pharynx & $171 \times 197$ & $126-177 \times 141-171(150 \times 161)$ & $139 \times 143$ \\
\hline Oesophagus & 36 & 68-107 (91) & 88 \\
\hline IB to VS & 142 & $136-168(149)$ & 0 \\
\hline Ventral sucker & $295 \times ?$ & $206-298 \times 203-253(255 \times 224)$ & $221 \times 216$ \\
\hline Cirrus-sac & ? & $593-686 \times 91-102(639 \times 96)$ & $562 \times 79$ \\
\hline Cirrus-overlap into hindbody & ? & $373-525(449)$ & 368 \\
\hline VS to vitellarium & $?$ & $42-100(76)$ & 0 \\
\hline VS to ovary & 625 & $587-809(677)$ & 514 \\
\hline Ovary & $150 \times 157$ & $144-217 \times 97-158(175 \times 132)$ & $117 \times 106$ \\
\hline Ovary to anterior testis & 85 & $44-92(61)$ & 100.3 \\
\hline Anterior testis & $206 \times 185$ & $205-285 \times 167-220(235)$ & $179 \times 143$ \\
\hline Distance between testes & 24 & 0 & 93.9 \\
\hline Posterior testis & $222 \times 185$ & $230-283 \times 172-217(259 \times 192)$ & $162 \times 135$ \\
\hline Post-testicular region & 365 & $327-486(409)$ & 377.8 \\
\hline Eggs & $80 \times 35$ & $75-79 \times 34-35(77 \times 34)$ & $74 \times 29$ \\
\hline Width $\% *$ & 17.5 & $12.7-15.4(14.1)$ & 15.0 \\
\hline Forebody $\% *$ & 26.5 & $27.7-28.0(27.9)$ & 30.6 \\
\hline Sucker-length ratio & $1: 2.00$ & $1: 1.86-2.15(1: 1.98)$ & $1: 1.71$ \\
\hline Sucker-width ratio & $? ?$ & $1: 1.23-1.37(1: 1.29)$ & $1: 1.16$ \\
\hline Cirrus-sac length\%* & $?$ & $19.5-20.4(19.9)$ & 22.0 \\
\hline VS-CS\%VS-Ov & $?$ & $58.8-65.0(61.9)$ & 71.5 \\
\hline VS to vitellarium $\% *$ & 0 & $1.40-3.23(2.53)$ & 0 \\
\hline VS-Ov\%* & 21.3 & $20.8-24.1(22.4)$ & 20.1 \\
\hline Ov-AT\%* & 2.89 & $1.31-3.50(2.12)$ & 3.92 \\
\hline Distance between testes\%* & 0.80 & 0 & 3.67 \\
\hline Post-testicular region\%* & 12.4 & $12.3-16.0(13.6)$ & 14.8 \\
\hline Oral sucker length\%* & 5.02 & $3.97-4.76(4.27)$ & 5.04 \\
\hline Ventral sucker length $\% *$ & 10.1 & $7.88-8.86(8.43)$ & 8.63 \\
\hline Prepharynx\%* & 9.58 & $9.98-11.0(10.6)$ & 13.2 \\
\hline Pharynx length\%* & 5.82 & $4.80-5.28(4.97)$ & 5.43 \\
\hline Anterior testis length\%* & 7.01 & $7.11-8.48(7.81)$ & 7.01 \\
\hline Posterior testis length\%* & 7.55 & $8.43-8.79(8.63)$ & 6.35 \\
\hline Ovary length\%* & 5.11 & $5.41-6.47(5.79)$ & 4.56 \\
\hline Hindbody (HB) & 1,861 & $1,682-2,123(1,915)$ & 1,554 \\
\hline Hindbody\%* & 63.5 & $63.1-64.2(63.7)$ & 60.8 \\
\hline VS-Vit \% HB & ? & $2.19-5.02(3.97)$ & 0 \\
\hline Genital atrium & ? & $98-157(136)$ & 183 \\
\hline Ejaculatory duct & $?$ & $245-327(284)$ & 260 \\
\hline Pars prostatica & $?$ & $126-216(162)$ & 221 \\
\hline Seminal vesicle length & $?$ & $141-316(251)$ & 145 \\
\hline Male duct & $?$ & $530-858(696)$ & 626 \\
\hline Ejaculatory duct $\%$ male duct & $?$ & $38.1-46.3(41.4)$ & 41.6 \\
\hline Pars prostatica $\%$ male duct & $?$ & $18.0-27.0(23.4)$ & 35.3 \\
\hline SV length $\%$ male duct & ? & $26.7-42.1(35.2)$ & 23.2 \\
\hline
\end{tabular}




\section{Stephanostomum uku Yamaguti, 1970}

H o s t: Aprion virescens Valenciennes, Lutjanidae, green jobfish. S it e: Posterior intestine.

L o c a lity: Reef near Îlot La Regnière $\left(22^{\circ} 19^{\prime} \mathrm{S}, 166^{\circ} 20^{\prime} \mathrm{E}\right.$, 05/07/2005), off Nouméa, New Caledonia.

Prevalence: 1 of 2 .

Vouchers: MNHN JNC1557C.

Discussion. This species is known only from $A$. virescens, in Hawaii (Yamaguti 1970) and a report of immature specimens from Lizard Island, Great Barrier Reef (Bray et al. 2005).

Acknowledgements. Many students and colleagues were involved in the fishing expeditions and the parasitological survey, especially Aude Sigura, Charlotte Schoelinck, Cyndie Dupoux, Isabelle Mary, Frank Moravec, Eva Řehulková and Nad'a Musilová. Xavier Neyrat (Aquarium des Lagons, Nouméa) collected the conger. The identification of several fishes was confirmed, from photographs, by ichthyologists: conger: Bernard Séret (MNHN, Paris); carangids: Ronald Fricke (Staatliches Museum für Naturkunde, Stuttgart); groupers: John E. Randall (Bishop Museum, Hawaii).

\section{REFERENCES}

Bartoli P., Bray R.A. 2001: Contribution to the knowledge of species of the genus Stephanostomum Looss, 1899 (Digenea: Acanthocolpidae) from teleosts of the Western Mediterranean, with the description of $S$. gaidropsari n. sp. Syst. Parasitol. 49: 159-188.

Bartoli P., Bray R.A. 2004: Four species of Stephanostomum Looss, 1899 (Digenea, Acanthocolpidae) from Seriola dumerili (Risso) (Teleostei, Carangidae) in the Western Mediterranean, including $S$. euzeti n. sp. Syst. Parasitol. 58: 41-62.

BraY R.A. 2005: Family Acanthocolpidae Lühe, 1906. In: A. Jones, R.A. Bray and D.I. Gibson (Eds.), Keys to the Trematoda. Volume 2. CABI Publishing and the Natural History Museum, Wallingford, pp. 603-619.

Bray R.A., CRIBB T.H. 2003: Species of Stephanostomum Looss, 1899 (Digenea: Acanthocolpidae) from fishes of Australian and South Pacific waters, including five new species. Syst. Parasitol. 55: 159-197.

Bray R.A., Cribb T.H. 2004: Stephanostomum tantabiddii n. sp. (Digenea: Acanthocolpidae) from Carangoides fulvoguttatus (Forsskål, 1775) (Perciformes: Carangidae), from Ningaloo Reef, Western Australia. Zootaxa 457: 1-8.

Bray R.A., CribB T.H. 2006: Stephanostomum talakitok n. sp. (Digenea: Acanthocolpidae) from Gnathanodon speciosus (Perciformes: Carangidae) from Ningaloo Reef, Western Australia. Zootaxa 1104: 59-68.

Bray R.A., CribB T.H. 2007: Monostephanostomum nolani sp. n. and M. krusei Reimer, 1983 (Digenea: Acanthocolpidae) from carangid fishes from coral reef waters off Australia. Folia Parasitol. 54: 19-26.

Bray R.A., CRibB T.H. 2008: Stephanostomum spp. (Digenea: Acanthocolpidae) from scombrids and carangids (Perciformes) from the Great Barrier Reef, with the description of two new species. Rev. Mex. Biodivers. 79: 49S-68S.

Bray R.A., Cribb T.H., Waeschenbach A., Littlewood D.T.J. 2007: A new species of Stephanostomum Looss, 1899 (Digenea: Acanthocolpidae) with a bizarre oral sucker: $S$. adlardi n. sp. from the common coral trout Plectropomus leopardus (Lacepède, 1802) (Perciformes: Serranidae) from Lizard Island, Great Barrier Reef. Acta Parasitol. 52: 206-212.

Bray R.A., Justine J.-L. 2007: Pseudopycnadena tendu sp. nov. (Digenea, Opecoelidae) in the yellow-spotted triggerfish Pseudobalistes fuscus (Perciformes, Balistidae) and additional opecoelids parasitizing fishes from the waters off New Caledonia. Acta Parasitol. 52: 13-17.

Bray R.A., ReImer L.W. 2004: Two species of Stephanostomum Looss, 1899 (Digenea: Acanthocolpidae) from marine fishes off
Namibia, including S. beukelaardori n. sp. Syst. Parasitol. 58: 209-216.

Bray R.A., Webster B.L., Bartoli P., Littlewood D.T.J. 2005: Relationships within the Acanthocolpidae Lühe, 1906 and their place among the Digenea. Acta Parasitol. 50: 281-291.

CribB T.H., Bray R.A. 2010: Gut wash, body soak, blender, and heat-fixation: approaches to the effective collection, fixation and preservation of trematodes of fishes. Syst. Parasitol. 55: 45-52.

Durio W.O., Manter H.W. 1969: Some digenetic trematodes of marine fishes of New Caledonia. III. Acanthocolpidae, Haploporidae, Gyliauchenidae, and Cryptogonimidae. J. Parasitol. 55: $293-300$.

Etchegoin J.A., Lanfranchi A.L., Cremonte F., Timi J.T. 2006: A new species of Acaenodera (Digenea: Acanthocolpidae) parasitizing Conger orbignyanus (Pisces: Congridae) from the coasts of Argentina. Parasitol. Int. 55: 291-293.

Fischthal J.H. 1977: Some digenetic trematodes of marine fishes from the Barrier Reef and Reef Lagoon of Belize. Zool. Scripta 6: $81-88$.

Fischthal J.H., Thomas J.D. 1968: Digenetic trematodes of marine fishes from Ghana: Families Acanthocolpidae, Bucephalidae, Didymozoidae. Proc. Helminthol. Soc. Wash. 35: 237-247.

Gu C.-D., Shen J.-W. 1983: Digenetic trematodes of fishes from the Xisha Islands, Guangdong Province, China. I. Stud. Mar. Sin. 20: 157-184. (In Chinese.)

Justine J.-L., Beveridge I., Boxshall G.A., Bray R.A., Moravec F., Trilles J.-P., Whittington I.D. 2010: An annotated list of parasites (Isopoda, Copepoda, Monogenea, Digenea, Cestoda and Nematoda) collected in groupers (Serranidae, Epinephelinae) in New Caledonia emphasizes parasite biodiversity in coral reef fish. Folia Parasitol. 57: 237-262 .

Lorber J., Cribb T., Moravec F., Kininger R., Konecny R. 2006: Endoparasiten von Fischen der Malediven. In: Helminthologische Fachgespräche 2006 'Von Würmern und Wirten', Naturhistorisches Museum, Wien, pp. 4-5.

Lozano C., Ubeda J.M., De Rojas M., Ariza C., Guevara D.C. 2001: Estudio de digénidos de peces marinos del sur de la Península Ibérica. Res. Rev. Parasitol. 61: 103-116.

MacCallum G.A. 1917: Some new forms of parasitic worms. Zoopathologica 1: 43-75.

Machida M. 1984: Trematodes of marine fishes from depth of 200-400 m off Yamagata, the Japan Sea. Mem. Natl. Sci. Mus., Tokyo 17: 101-110.

Madhavi R. 1976: Digenetic trematodes from marine fishes of Waltair Coast, Bay of Bengal. Family Acanthocolpidae. Riv. Parassitol. 37: 115-128. 
Manter H.W. 1926: Some North American fish trematodes. Ill. Biol. Monogr. 10: 7-138.

Manter H.W. 1940: Digenetic trematodes of fishes from the Galapagos Islands and the neighboring Pacific. Allan Hancock Pacif. Exped. 2: 325-497.

MANTER H.W. 1947: The digenetic trematodes of marine fishes of Tortugas, Florida. Am. Midl. Nat. 38: 257-416.

Manter H.W., Pritchard M.H. 1960: Some digenetic trematodes of eels of Hawaii. J. Parasitol. 46: 651-658.

Miller T.L., Cribb T.H. 2007: Phylogenetic relationships of some common Indo-Pacific snappers (Perciformes: Lutjanidae) based on mitochondrial DNA sequences, with comments on the taxonomic position of the Caesioninae. Mol. Phylogenet. Evol. 44: $450-460$.

Nahhas F.M., Cable R.M. 1964: Digenetic and aspidogastrid trematodes from marine fishes of Curaçao and Jamaica. Tulane Stud. Zool. 11: 169-228.

Nahhas F.M., Nasser H., Tam J. 2004: Digenetic trematodes of marine fishes from Suva, Fiji: families: Acanthocolpidae, Lepocreadiidae, Bivesiculidae, Zoogonidae, Monorchiidae and description of a new species. Riv. Parassitol. 21: 33-48.

Nahhas F.M., Powell E.C. 1971: Digenetic trematodes of marine fishes from the Floridian northern Gulf of Mexico. Tulane Stud. Zool. Bot. 17: 1-9.

Nahнas F.M., Short R.B. 1965: Digenetic trematodes of marine fishes from Apalachee Bay, Gulf of Mexico. Tulane Stud. Zool. 12: $39-50$.

Nicoll W. 1907: A contribution towards a knowledge of the Entozoa of British marine fishes. Part 1. Ann. Mag. Nat. Hist., 7 Ser., 19: 66-94.

NicolL W. 1913: Trematode parasites from food-fishes of the North Sea. Parasitology 6: 188-194.

Overstreet R.M. 1969: Digenetic trematodes of marine teleost fishes from Biscayne Bay, Florida. Tulane Stud. Zool. Bot. 15: 119-176.

Received 2 August 2010
Parukhin A.M. 1970: [On the study of trematode fauna in fish from the Red Sea and Aden Bay]. Biol. Morya, Kiev 20: 187213. (In Russian.)

Saoud M.F.A., Nahhas F.M., Al Kuwari K.S.R., Ramadan M.M. 2002: Helminth parasites of fishes from the Arabian Gulf: 10. Trematodes of the genus Stephanostomum Looss, 1899 (Digenea: Acanthocolpidae Lühe, 1901), with description of Stephanostomum qatarense n. sp. and redescription of Stephanostomum triacanthi Madhavi, 1976. Riv. Parassitol. 29 (63): 87-103.

Shaukat N., Bilqees F.M. 2007: A new species of the genus Stephanostomum Looss, 1899 (Digenea: Acanthocolpidae) from the fish Pomadasys olivaceum off Karachi coast. Proc. Parasitol. 44: 45-67.

Sparks A.K. 1958: Some digenetic trematodes of fishes of Grand Isle, Louisiana. Proc. La. Acad. Sci. 20: 71-82.

Stossich M. 1883: Brani di elmintologia tergestina. Serie prima. Boll. Soc. Adriat. Sci. Nat. 8: 111-121.

Wolfgang R.W. 1955: Studies on the trematode Stephanostomum baccatum (Nicoll, 1907). III. Its life cycle. Can. J. Zool. 33: $113-128$.

Yamaguti S. 1934: Studies on the helminth fauna of Japan. Part 2. Trematodes of fishes, I. Jpn. J. Zool. 5: 249-541.

Yamaguti S. 1939: Studies on the helminth fauna of Japan. Part 26. Trematodes of fishes, VI. Jpn. J. Zool. 8: 211-230.

Yamaguti S. 1970: Digenetic trematodes of Hawaiian fishes. Keigaku, Tokyo, $436 \mathrm{pp}$.

Zнuкоv E.V. 1960: Endoparasitic worms of the fishes in the Sea of Japan and South-Kuril shallow-waters. Trud. Zool. Inst., Leningr. 28: 3-146. (In Russian.)

Zhuкоv E.V. 1977: Contribution to the knowledge of trematodes of marine fishes of India. Parazitol. Sb. 27: 51-79. (In Russian.)

Accepted 6 October 2010 